\title{
Kaligesing Goat Productivity by Giving Fermented Animal Herbal Medicine
}

\author{
Roisu Eny Mudawaroch ${ }^{1}$, Zulfanita $^{2}$ \\ \{roisueny@umpwr.ac.id ${ }^{1}$ \} \\ Animal husbandry, Agriculture, Universitas Muhammadiyah Purworejo, Indonesia ${ }^{1,2}$
}

\begin{abstract}
The research objective was to determine the productivity of kaligesing goats by providing fermenatal animal herbal medicine. PO treatment is a control that is without the addition of fermented animal herbal medicine, P50 is the provision of animal fermented herbal medicine as much as $50 \mathrm{ml} /$ head / day, P100 is the provision of animal fermented herbal medicine as much as $100 \mathrm{ml} /$ head / day, and P150 is the provision of animal fermented herbal medicine as much as $100 \mathrm{ml} /$ head / day. $100 \mathrm{ml} /$ head / day of herbal medicine. animal herbal medicine as much as $150 \mathrm{ml} / \mathrm{head} /$ day. The results of this study were the body weight of the Kaligesing goat in this study ranged from $16.33 \pm 1.20-20.25$ $\pm 2.14 \mathrm{~kg}$. Provision of fermented animal herbal medicine as much as $50 \mathrm{ml} /$ head / day can increase body weight gain. The increase in body weight in the control treatment, namely $29.8 \pm 5.95$, increased to $178.57 \pm 35.71$ with the addition of fermented herbal medicine of $50 \mathrm{ml} /$ head / day. Consumption of goats or kaligesing goats in this study ranged from $160.34 \pm 2-201.44 \pm 0.06$. The feed conversion in the treatment ranged from $15.77 \pm 5.32$ to $66.59 \pm 29.28$. Provision of fermented animal herbal medicine as much as $50 \mathrm{ml} /$ head / day can increase feed efficiency. The feed efficiency in this study ranged from $10.02 \pm 1.96 \%-69.09 \pm 14.79 \%$. The conclusion of this study is that the initial body weight of the Kaligesing goat shows no significant effect.
\end{abstract}

Keywords: Etawah, fermented, animal, herbal, medicine

\section{Introduction}

The development and interest of breeders in cultivating Ettawa goats is increasing rapidly from year to year. The results obtained from raising Ettawa goats include sales of broodstock, calves and milk. Another addition is the result of processing goat manure into organic fertilizer. Apart from the results obtained above, currently what is booming in the market is the sale of ettawa goat milk [1]. Ettawah goat is a dual-purpose goat, which is a milk and meat producer developed in Kaligesing District, Purworejo Regency, Indonesia since 1932. At that time the Dutch government brought ettawa cows from India to be crossed with local goats (goat beans). The results of these crosses were raised by the community in Kaligesing District, Purworejo Regency. The aim of the Dutch government to bring in Ettawa goats from India was to utilize waste from a plantation that was being developed in Kaligesing District, Purworejo Regency. The ettawa goat crossed with local goats produces crossed ettawa, with the aim of getting sires with high productivity and can live well in conditions in Indonesia. During its development, crossbreed ettawah goats grew faster in other areas than in Kaligesing itself. To maintain Ettawah Peranakan goat germplasm, the Government of the Republic of Indonesia issued a Decree of the Minister of Agriculture of the Republic of Indonesia Number 346 / Kpts / PK.020 
/ 5/2016 as a source area for Kaligesing goat seeds [2]. Most of the Kaligesing goat farms in Kaligesing were not well managed, especially in terms of feed and health. To increase production, it is necessary to fulfill the nutritional and health needs of Kaligesing goats by providing supplementation feed.

Kaligesing area is a mountainous area planted with plantation crops and planted with empon-empon [3]. Farmers can harvest empon-empon at any time while waiting for a long harvest for plantation crops [4]. The existence of these empon-empons makes it easier for breeders to obtain traditional medicines, so that traditional medicines can be obtained from the surrounding environment. Factory-made drugs have high prices and chemicals so farmers have other alternatives in caring for their animals by providing animal herbal medicine. Animal jamu is a medicinal plant made according to its interests and functions which were usually selected from one type or several types of medicinal plants. This fermented animal herbal medicine is made with a mixture of 9 medicinal plants, namely garlic, kencur, ginger, galangal, turmeric, ginger, cinnamon, god's crown then mixed with molasses or brown sugar and EM4. This mixture is fermented for 6 days [5]. Animal herbal fermentation is one of the technologies in the manufacture of animal herbal medicine. The provision of animal fermented herbal medicine has been widely used in chickens which resulted in a decrease in the percentage of belly fat [6]. The application of animal herbal medicine is also carried out on sheep to improve feed digestibility [7]. Giving herbs to etawah crossbred goats only on a few empon-empon, namely ginger (ginger) and turmeric (curcuma domestic val) which can increase body weight gain [8]. The application of fermented animal herbal medicine with a composition of 9 medicinal plants, molasses or brown sugar and EM4 in goats has never been done. Therefore, it is necessary to do research on fermented animal herbal medicine on the productivity of Kaligesing Goats. Kaligasing goat productivity can be observed at initial growth, body weight gain, feed consumption, feed conversion ratio and feed efficiency. The purpose of this study was to determine the productivity of kaligesing goats by giving fermented animal herbs.

\section{Method}

\subsection{Research material}

The research location was conducted in the Ngudimulyo Farmers Group, Kaligono Kaligesing Village, Purworejo District, Central Java Province, Indonesia. The materials used were 12 female Kaligesing goats with a body weight of $14-24.5 \mathrm{~kg}$. The tools used during the implementation of the research include: an experimental cage, a set of tools for making fermented animal herbal medicine and a scale. The basal material used is the leaves of waru and leaves of gamal. The medicinal feed is fermented animal herbal medicine.

\subsection{Research procedure}

Basal feed is given twice a day, namely during the day and at night. Feed and water were given adlibitum. Fermented animal herbal medicine is given every day with a dose according to treatment. The composition of the herbal fermentation ingredients [5] is presented in Table 1. The process of making fermented herbal medicine is presented in Figure 1. 
Table 1. Composition of ingredients for fermented animal herbal medicine

\begin{tabular}{|c|c|c|c|}
\hline Ingredients for medicinal plants and spices & Part used & Total & \\
\hline Garlic (Allium sativum L) & Root tubers & $250 \mathrm{~g}$ & Antibacterial [9] \\
\hline Galagal (Kaempferia galangal L) & Rhizome & $250 \mathrm{~g}$ & $\begin{array}{l}\text { Antimicrobial [5], Anti } \\
\text { Fungal [10] }\end{array}$ \\
\hline Ginger (Gingiber officinale Rose) & Rhizome & $125 \mathrm{~g}$ & Palability [5] \\
\hline Galangal (Langkuas galangal Stunz) & Rhizome & $125 \mathrm{~g}$ & Anti Fungal [10] \\
\hline Turmeric (Curcuma domesatica Val) & Rhizome & $125 \mathrm{~g}$ & Antimicrobial [5] \\
\hline Temulawak (Curcuma xanthorhiza Roxb) & Rhizome & $125 \mathrm{~g}$ & Palability [8] \\
\hline Cinnamon (Curcuma burmanii B) & Bark & $62,5 \mathrm{~g}$ & Antimicrobial [5] \\
\hline Betel (Piper betle L) & Leaf & $62,5 \mathrm{~g}$ & Antibacterial [11] \\
\hline $\begin{array}{l}\text { The crown of the god (Phaleria macrocorpa } \\
\text { Boerl) }\end{array}$ & Leaf & $62,5 \mathrm{~g}$ & Antibacterial [12] \\
\hline Molasses or brown sugar & Solution & $250 \mathrm{ml}$ & Energy Sources [13] \\
\hline EM4 atau M-Bio & Solution & $250 \mathrm{ml}$ & $\begin{array}{l}\text { Source } \\
\text { Microorganisms }\end{array}$ \\
\hline
\end{tabular}

The experimental design used was a randomized block design with 4 treatments and 3 replications. The treatment in this study was the level of giving fermented animal herbal medicine with the composition:

$\mathrm{P0}=$ basic feed + without the addition of fermented animal herbs

P50 = basic feed + fermented animal herbs as much as $50 \mathrm{ml}$ per day

$\mathrm{P} 100=$ basic feed + fermented animal herbs as much as $100 \mathrm{ml}$ per day

$\mathrm{P} 150=$ basic feed + fermented animal herbs as much as $150 \mathrm{ml}$ per day

The pre-research was conducted for 2 weeks so that the goats could adapt to the research feed. Data were taken for 4 weeks. The parameters observed in this study were:

- Initial weigh. Initial body weight was measured by weighing the weight of each kaligesing goat at the start of the study

- Weight gain. Measurement of weight gain used the method [14], namely the gain of body weight by weighing each goat and carried out every week.

- Feed consumption. Feed consumption was measured by weighing the feed given ( $\mathrm{g} /$ head / day) - remaining feed (g / head / day) [15].

- Feed conversion. Feed conversion was obtained by dividing the amount of feed consumed by the body weight gain during maintenance [15].

- Feed efficiency. Feed efficiency was obtained by dividing the number of daily body weight with feed consumed with the same unit weight [8]. 


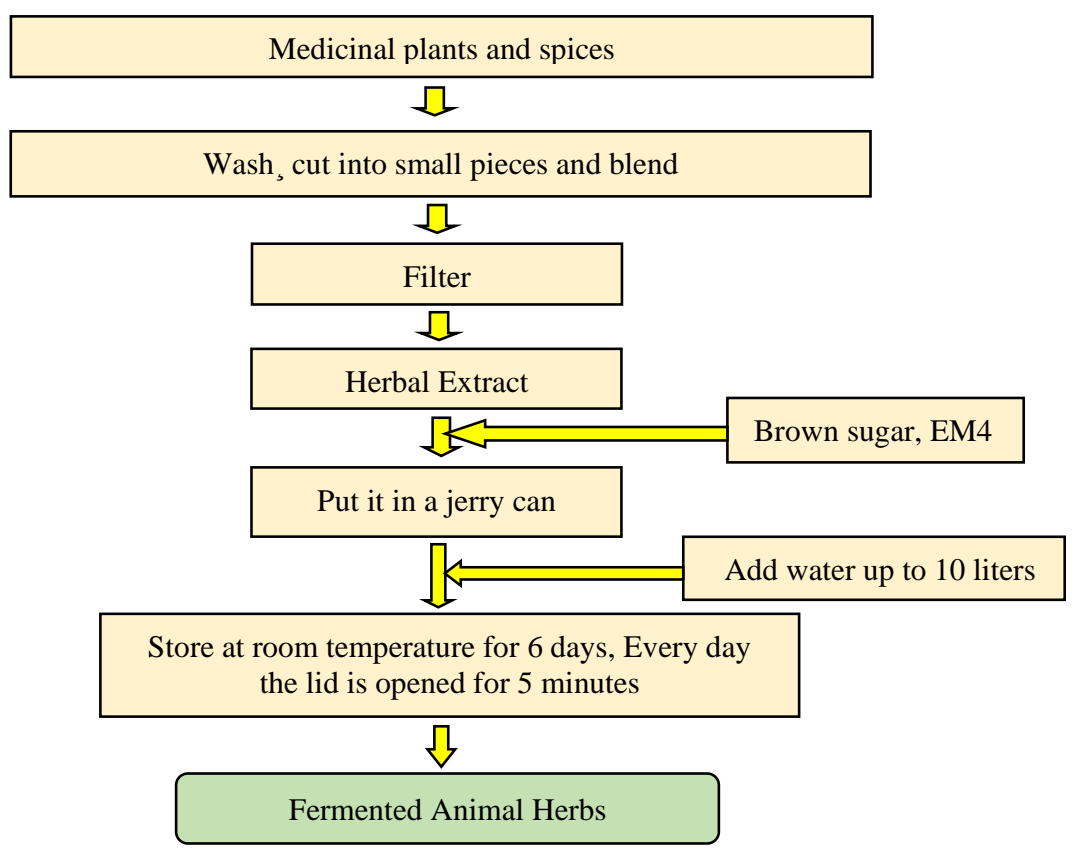

Fig. 1. The process of making fermented animal herbal medicine

\subsection{Statistic analysis}

The data obtained were analyzed using analysis of variance (ANOVA) with the help of SPSS 18. If there was a significant difference, it will be followed by Duncan's distance test.

\section{Result and Discussion}

The average initial body weight, body weight gain, feed consumption, feed conversion and feed efficiency of Kaligesing goats with the addition of fermented animal herbs werepresented in Table 2.

\subsection{Initial weight}

The average body weight was presented in Table 2 . The Kaligesing goat's body weight in this study ranged from $16.33 \pm 1.20-20.25 \pm 2.14 \mathrm{~kg}$. These results were still in the range of weight of cross-breed female Kaligesingh goats, namely $16.80 \mathrm{~kg}$ [16] and $35.00 \mathrm{~kg}$ [17]. The results of the analysis of various initial body weight of the Kaligesing goat did not show a significant effect $(\mathrm{P}>0.05)$, so that the sample could be used for research with an acceptable degree of error. 
Table 2. Average initial body weight, body weight gain, feed intake, feed conversion and feed efficiency of Kaligesing Goats with the addition of fermented animal herbs

\begin{tabular}{lllll}
\hline Treatment & P0 & P50 & P100 & P150 \\
\hline Initial body weight & $20,25 \pm$ & $16,5 \pm 0,76$ & $16,33 \pm 1,20$ & $19,66 \pm 0,88$ \\
& 2,14 & & & \\
ADG (g/head/day) & $29,8 \pm$ & $178,57 \pm$ & $166,67 \pm$ & $130,95 \pm$ \\
& $5,95^{\mathrm{a}}$ & $35,71^{\mathrm{b}}$ & $23,81^{\mathrm{b}}$ & $11,90^{\mathrm{b}}$ \\
Feed intake (g/head/day) & $172,08 \pm$ & $201,44 \pm 9,452$ & $169,86 \pm 9,76$ & $160,34 \pm 16,42$ \\
& 16,64 & & & \\
FCR & $66,59 \pm$ & $18,68 \pm 8,08^{\mathrm{b}}$ & $15,77 \pm 5,32^{\mathrm{b}}$ & $21,18 \pm 1,64^{\mathrm{b}}$ \\
& $29,28^{\mathrm{a}}$ & & & \\
Feed efficiency & $10,02 \pm$ & $63,03 \pm 13,66^{\mathrm{a}}$ & $69,09 \pm 14,79^{\mathrm{a}}$ & $47,39 \pm 2,17^{\mathrm{a}}$ \\
& $1,96^{\mathrm{b}}$ & & & \\
\hline
\end{tabular}

P0: Control feed, P50: $50 \mathrm{ml}$ of fermented animal herbal medicine, P100: $100 \mathrm{ml}$ of fermented animal herbal medicine, P150: $150 \mathrm{ml}$ of fermented animal herbal medicine.

a,b different superscripts at the same row indicate significant differences $(\mathrm{P}<0.05))$.

\subsection{Average daily gain}

The average daily gain (ADG) was presented in Table 2. The Kaligesing goat's ADG in this study ranged from 29.8 - $178.57 \mathrm{~g} /$ day, this result was still in the range reported [18], namely $110.07 \pm 29.90 \mathrm{~g} . /$ day, and reported [19] was $59.00 \pm 19.23-67.58 \pm 17.5$. The results of the analysis of the variety of giving fermented animal herbal medicine to Kaligesing goats showed a significant effect $(\mathrm{P}<0.05)$ on $\mathrm{ADG}$. The addition of herbs increases ADG, this was because herbs can reduce the protozoa population so that the growth of lactic acid bacteria in the rumen increases, while the Escherichia coli bacteria were inhibited by the presence of garlic. Herbs can also increase rumen fluid NH3 levels, and improve digestibility in-vitro [7][9]. medicinal plants containing active substances including terpenoids, alkaloids, flavonoids, essential oils, phenols, curcuminoid, allicin which often functions as antimicrobial, anti-fungal and antioxidant will suppress the growth of gram-negative bacteria and maintain endurance [9] [20-23]. The addition of EM-4 to herbal medicine, where EM-4 contains lactic acid bacteria which can lower the $\mathrm{pH}$ in the intestine. The decrease in $\mathrm{pH}$ in the digestive tract of the goat will increase the motility of the intestinal wall lining, so that the surface area of the intestinal wall increases, this will result in an increase in the absorption rate of the intestinal wall. Because many substances in the feed were absorbed, the physiological process of digestion was getting better, so that the animal body can form or increase the size of new tissue. Because many substances in the feed were absorbed, the physiological process of digestion was getting better, so that the animal body can form or increase the size of new tissue. The result of the growth or development of new tissue has an effect on ADG [24].

\subsection{Feed intake}

The average consumption of Kaligesing goats was presented in Table 2. Consumption of goats in this study ranged from $160.34 \pm 2-201.44 \pm 0.06$. This result was lower than reported [25] of $246.91-294.91 \mathrm{~g} / \mathrm{kg} /$ day and higher than reported [26] of $30.7-38.4 \mathrm{~g} / \mathrm{kg} / \mathrm{day}$. The results of the analysis of the diversity of the Kaligesing goat fermented herbal medicine did not show a significant effect $(\mathrm{P}>0.05)$ on feed consumption. The ingredients of jamu, namely ginger, galangal, turmeric, molasses, and cinnamon were used to increase appetite and maintain animal stamina [24]. Fermented animal herbal medicine containing empon-empon, namely 
ginger and turmeric, has an active substance, namely curcumin which increases the activity of the immune system in animals. The essential oil in curcumin stimulates the central nervous system, which in turn results in increased appetite and nutrient consumption. However, fermented animal herbal medicine has a sour taste which reduces its delicacy. better palatability of fresh feed than fermented feed [27]. So that feed consumption does not show a real difference.

\subsection{Feed conversion ratio}

The average feed conversion ratio for Kaligesing goats can be seen in Table 3. Feed conversion in the treatment ranged from $15.77 \pm 5.32-66.59 \pm 29.28$. These results were within the reported ranges [28]. from $42-17.8$ and 51.37 - 91.75 to 67.75 . The results of the analysis of the variety of animal herbal medicine for etawah Kaligesing goat showed a significant effect $(\mathrm{P}<0.05)$ on the feed conversion ratio. The feed conversion ratio was an indicator that can provide an overview of the level of efficiency of use. The lower the FCR, the higher the efficiency of ration use. The use of fermented animal herbal medicine will reduce feed conversion, although it does not affect feed consumption. Fermented animal herbal medicine contains spices that can suppress the growth of protozoa so that the growth of bacteria, especially lactic acid bacteria, increases. The increase in lactic acid bacteria in the rumen will suppress the growth of E coli bacteria. These results were the same as those reported by [7] that giving herbs will increase the digestibility of feed. In addition to medicinal plant content, fermenatic animal herbal medicine also contains EM4 which will aid in digestion of food. Probiotics (EM-4) can balance microorganisms in the digestive tract of animals, increase appetite, nourish animals, reduce stress, improve the quality of animal production, reduce cage odors and the environment [29]. Herbal medicine can increase feed efficiency through FCR (Feed Convertion Ratio) [30].

\subsection{Feed efficiency}

The results of the analysis of the variety of the provision of fermented animal herbal medicine to the Kaligesing goat showed significantly different results $(\mathrm{P}<0.05)$ on feed efficiency. The average feed efficiency of the Kaligesing goat was shown in Table 3. The feed efficiency in this study ranged from $10.02 \pm 1.96 \%-69.09 \pm 14.79 \%$. Feed efficiency of male Ettawa goats feeding Temulawak (Curcuma xhanthoriza Roxb) and turmeric (Curcuma domestik Val) resulted in feed efficiency of 18.25-23.34\% [8]. Feed efficiency was the opposite of feed conversion, the higher the feed efficiency value, the less feed was needed to produce one kilogram of meat. The addition of fermented animal herbal medicine increases feed efficiency. fermented animal herbal medicine contains active ingredients that were able to suppress the protozoa population, so that bacteria and fungi develop well so that they can degrade fibrous feed more optimally, thereby increasing the digestibility of the feed. Kaligesing goat feed with high fiber can be digested maximally in the rumen with the addition of fermented animal herbs. The provision of fermented animal herbal medicine will increase the speed of feed travel in the Kaligesing goat's rumen thereby increasing feed efficiency. Factors that affect feed efficiency include the speed of feed travel in the digestive tract, the physical form of the feed, and the nutritional composition of the ration. 


\section{Conclusion}

The body weight of the Kaligesing goat in this study ranged from $16.33 \pm 1.20-20.25 \pm$ $2.14 \mathrm{~kg}$ showing an insignificant effect, so the sample can be used for research with degrees of error that was acceptable. The addition of $50 \mathrm{ml} /$ day of fermented animal herbal medicine did not affect feed consumption. The addition of $50 \mathrm{ml} /$ day of fermented animal herbal medicine increases weight gain, reduces feed conversion and increases feed efficiency of Kaligesing goats. The suggestion in this research was that it was necessary to add animal fermented herbal medicine as much as $50 \mathrm{ml}$ / day / head to Etawa Kaligesing goat to increase its productivity.

\section{Acknowledgement}

The authors thank to Directorate General of Higher Education, Ministry of National Education of Indonesia for funding assistance in research grants and to Institute for research and service (LPPM) Muhammadiyah University of Purworejo for the motivation given.

\section{References}

[1] H. Wasiati and E. Faizal, "Peternakan Kambing Peranakan Etawa Di Kabupaten Bantul," J. Pengabdi. Masy. Univ. Merdeka Malang, vol. 3, no. 1, 2018, doi: 10.26905/abdimas.v3i1.2242.

[2] Menteri Pertanian, "Surat Keputusan Menteri Pertanian Republik Indonesia Nomor Nomor 346/Kpts/PK.020/5/2016 tentang Penetapan Kabupaten Purworejo Sebagai Wilayah Sumber Bibit Kambing Kaligesing,” 2016.

[3] N. Haryanti, "Karakteristik Masyarakat Tani Tawangsari Jawa Tengah pada Keberhasilan Adopsi keberhasilan Teknologi Konservasi," Indones. Rehabil. J., vol. 2, no. 2, pp. 145-163, 2014.

[4] S. N. Iftitah and G. Harono, "Pengkajian beberapa tanaman empon - empon di desa balesari kecamatan windusari kabupaten magelang," VIGORJurnal Ilmu Pertan. Trop. dan Subtrop., vol. 3, no. 1, pp. 13-16, 2018.

[5] D. Zainuddin, "Tanaman Obat Meningkatkan Efisiensi Pakan Dan Kesehatan Ternak Unggas," Lokakarya Nas. Inov. Teknol. Dalam Mendukung Usaha Ternak Unggas Berdaya saing, pp. 202 209, 2006.

[6] Y. Tahalele, M. E. R. Montong, F. J. Nangoy, and C. L. K. Sarajar, "Pengaruh Penambahan Ramuan Herbal Pada Air Minum Terhadap Persentase Karkas, Persentase Lemak Abdomen Dan Persentase Hati Pada Ayam Kampung Supero Title,” vol. 38, no. 1, pp. 160-168, 2019, doi: 10.1017/CBO9781107415324.004.

[7] E. Marhaeniyanto, "Pengaruh Pemberian Jamu Tradisional Terhadap Kecernaan Pakan Pada Ternak Domba," Buana Sains, vol. 10, no. Vol 10, No 1 (2010), pp. 19-28, 2010.

[8] C. Arum Aulia Kartika, "Pengaruh Pemberian Temulawak (Curcuma Xhanthoriza Roxb) dan kunyit (Curcuma Domestic Val) Terhadap Pertambahan Bobot Badan Kambing Peranakan Ettawa Jantan," Universitas Jambi, 2017.

[9] Zulfanita, R. E. Mudawaroch, and Rinawidiastuti, "Potensi Bawang Putih (Allium sativum) Sebagai Anti Bakteri," in Pengenrbangan Potensi Sumberdaya Lokal berwawasan Lingkungan untuk Penguatan Prorluk Pertanian Nasional Berdaya Saing Global, 2016, vol. 53, no. 9, pp. 1689-1699.

[10] U. W. Darmawan and I. Anggraeni, "Pengaruh Ekstrak Rimpang Kunyit (Curcuma domestica Val), Lengkuas (Languas galanga L.) Stunz dan Kencur (Kaempferia galanga L.) Terhadap Pythium sp. Secara In-Vitro," J. Penelit. Hutan Tanam., vol. 9, no. 3, pp. 135-140, 2012, doi: 10.20886/jpht.2012.9.3.135-140. 
[11] S. Kursia, J. S. Lebang, B. Taebe, A. Burhan, W. O. . Rahim, and Nursamsiar, "Uji Aktivitas Antibakteri Ekstrak Etilasetat Daun Sirih Hijau (Piper betle L.) terhadap Bakteri Staphylococcus epidermidis," Indones. J. Pharm. Sci. Technol., vol. 3, no. 2, pp. 72-77, 2016.

[12] M. Afnizar, N. Mahdi, and Zuraidah, "Uji Aktivitas Anti Bakteri Ekstrak Daun Mahkota Dewa (Phaleria macrocarpa) Terhadap Bakteri Staphylococcus aureus," Pros. Semin. Nas. Biot. 2016, pp. 293-300, 2016.

[13] S. Wuysang, C. A. Rahasia, J. F. Umboh, and Y. L. R. Tulung, "Pengaruh Penggunaan Molases Sebagai Sumber Energi Pakan Penguat Dalam Ransum Terhadap Pertumbuhan Ternak Kelinci," J. Zootek, vol. 37, no. 1, pp. 149-155, 2017.

[14] M. L. Sari, S. Tantalo, K. Nova, and Department, "Performa Ayam Kub (Kampung Unggul Balitnak) Periode Grower Pada Pemberian Ransum Dengan Kadar Protein Kasar Yang Berbeda," J. Ris. dan Inov. Peternak., vol. 53, no. 9, pp. 1689-1699, 2019, doi: 10.1017/CBO9781107415324.004.

[15] H. Hidayat, H. D. Arifin, and R. E. Mudawaroch, "2019Pengaruh Subsitusi Jerami Padi Fermentasi Terhadap Produktifitas Kambing Pe Jantan,” Surya Agritama, vol. 8, pp. 95-104, 2019.

[16] Lutojo and H. Irianto, "Tampilan Produksi Kambing Peranakan Etawa PE Jantan yang diberi Pakan Suplemen Urea Molasses Blok Plus Antihelmintic Agents (UMMB Plus)," Caraka Tani, vol. 26, no. 1, pp. 23-27, 2011.

[17] N. Rasminati, "Grade Kambing Peranakan Ettawa pada Kondisi Wilayah yang Berbeda," Sains Peternak., vol. 12, no. 1, p. 43, 2017, doi: 10.20961/sainspet.11.1.43-48.

[18] M. L. Rohmani, "Perbedaan Pertambahan Bobot Badan Harian Kambing Peranakan Ettawa (Pe) Ras Kaligesing Dan Ras Senduro Pada Periode Prasapih Di UPT PT Dan HMT Malang,” Universitas Brawijaya Malang, 2018.

[19] N. Zurahmah, S. Tinggi, and P. Pertanian, "Pengamatan Pertumbuhan Kambing Peranakan Etawah," vol. 8, no. 2, pp. 45-50, 2018.

[20] I. Ismoyowati, D. Indrasanti, M. Mufti, and A. S. Farjam, "Phytobiotic Properties of Garlic, Red Ginger, Turmeric and Kencur in Growing Ducks," Anim. Prod., vol. 17, no. 1, p. 49, 2015, doi: 10.20884/1.anprod.2015.17.1.484.

[21] S. S. Prihandani, "Uji Daya Antibakteri Bawang Putih (Allium sativum L.) Terhadap Bakteri Staphylococcus aureus, Escherichia coli, Salmonella typhimurium dan Pseudomonas aeruginosa dalam Meningkatkan Keamanan Pangan," Inform. Pertan., vol. 24, no. 1, p. 53, 2015, doi: 10.21082/ip.v24n1.2015.p53-58.

[22] H. J. Shetu, K. T. Trisha, S. A. Sikta, R. Anwar, S. Sakib, and B. Rashed, "Pharmacological importance of Kaempferia galanga (Zingiberaceae ): A mini review," Int. J. Res. Pharm. Pharm. Sci., vol. 3, no. 3, pp. 32-39, 2018.

[23] Y. Farida and H. Sasongko, "Pemanfaatan Tanaman Lokal sebagai Pakan Ternak Fermentasi dan Suplemen Pakan di Desa Sendang , Kabupaten Wonogiri ( Utilization of Local Plant as Fermented Feed and Supplements for Livestock in Sendang Village, Wonogiri District )," Agrokreatif, vol. 4, no. 1, pp. 61-67, 2018.

[24] P. N. and J. P. S., "Pengaruh Pemberian Ramuan Herbal Sebagai Pengganti Vitamin dan Obat-Obatan dari Kimia Terhadap Performan Ternak Ayam Kampung Super,” J. Pengemb. Penyul. Pertan., vol. 11, no. 22, p. 97, 2015, doi: 10.36626/jppp.v11i22.141.

[25] Suparman, H. Hafid, and L. O. Baa, "Kajian Pertumbuhan dan Produksi Kambing Peranakan Ettawa Jantan Yang Diberi Pakan Berbeda," JITRO, vol. 3, no. 3, pp. 1-9, 2016.

[26] G. P. catur Pamungkas, Kusmartono, and Hermanto, "The Influence Of Grain Supplementation Of Corn (Zea Mays) Ith Against The Amount Of Consumption Of Feed, Feed Conversion, And Increase Body Weight Of A Boer Cross Breed Goat," BMC Public Health, vol. 5, no. 1, pp. 1-8, 2017.

[27] C. I. Novita, A. Sudono, I. K. Sutama, and T. Toharmat, "Produktivitas Kambing Peranakan Etawah yang Diberi Ransum Berbasis Jerami Padi Fermentasi,” Media Peternak., vol. 29, no. 2, pp. 96-106, 2006.

[28] S. Herijanto and E. Nurwantini, "Manipulasi Pola Pemberian Pakan Ternak Untuk Peningkatan Kinerja Produksi Kambing Peranakan Etawa (PE),” Media Peternak., vol. 13, no. 1, pp. 1-5, 2011.

[29] A. Wakhid, Beternak Itik. Jakarta: Agromedia, 2013. 
[30] Bursatriannyo, "Jamu Ternak Fermentasi Peningkat Imunitas," Pusat Penelitian dan Pengembangan Perkebunan (Puslitbangbun),

November 27th,

2013.

http://perkebunan.litbang.pertanian.go.id/jamu-ternak-fermentasi-peningkat-imunitas/. 